JęDRZEj BuJny, Tymoteusz Mądry

\title{
Problemy związane z definicją lasu w polskim systemie prawnym
}

\section{Wprowadzenie}

Uznanie danego gruntu za las w rozumieniu Ustawy z dnia 28 września 1991 r. o lasach ${ }^{1}$ wiąże się z doniosłymi skutkami prawnymi w licznych aspektach. Taka klasyfikacja rodzi wiele praktycznych problemów związanych m.in. z obciążeniami podatkowymi, możliwością zabudowy danego terenu czy uzyskaniem pozwolenia na usuwanie drzew i krzewów. Dlatego też poprawne zdekodowanie tego, jaki grunt jest lasem $\mathrm{w}$ rozumieniu ustawy o lasach, ma niezwykle istotne znaczenie, zwłaszcza dla właścicieli nieruchomości gruntowych mogących wpisywać się w ramy tego pojęcia. Tymczasem zarówno w piśmiennictwie, jak i orzecznictwie sądowym definicja pojęcia lasu nie jest rozumiana w sposób jednolity.

Niniejszy artykuł przedstawia definicję lasu przyjętą w art. 3 u.l., przybliża także kontrowersje i niejednoznaczności związane z procesem wykładni tego przepisu, a także omawia praktyczne problemy, jakie mogą powstać podczas jego stosowania przez organy władzy publicznej.

\section{Definicja lasu zawarta w ustawie z 1991 r. o lasach}

Ustawa wprowadza legalną definicję pojęcia lasu. W myśl art. 3 u.l. lasem jest grunt:

${ }^{1}$ Tekst jedn. Dz.U. 2017, poz. 788, dalej „u.1.”. 
1) o zwartej powierzchni co najmniej 0,10 ha, pokryty roślinnością leśną (uprawami leśnymi) - drzewami i krzewami oraz runem leśnym lub przejściowo jej pozbawiony:

a) przeznaczony do produkcji leśnej lub

b) stanowiący rezerwat przyrody lub wchodzący w skład parku narodowego albo

c) wpisany do rejestru zabytków;

2) związany z gospodarką leśna, zajęty pod wykorzystywane dla potrzeb gospodarki leśnej: budynki i budowle, urządzenia melioracji wodnych, linie podziału przestrzennego lasu, drogi leśne, tereny pod liniami energetycznymi, szkółki leśne, miejsca składowania drewna, a także wykorzystywany na parkingi leśne i urządzenia turystyczne.

Jak widać, definicja lasu funkcjonująca na gruncie ustawy o lasach jest definicją złożoną, składającą się z kilku elementów. Dwa podstawowe elementy w jej treści wyróżnia B. Rakoczy. Pierwszy z nich związany jest z określoną powierzchnią gruntu, można go zatem określić mianem kryterium obszarowego, drugi dotyczy natomiast związku danego gruntu z gospodarką leśna, jest to zatem swoiste kryterium funkcjonalne ${ }^{2}$.

Nieco bardziej rozbudowaną klasyfikację elementów definicji lasu zawartych w przepisie art. 3 u.l. proponuje natomiast W. Radecki. Autor ten wskazuje, że na gruncie omawianej definicji legalnej pojęcie lasu konstytuują cztery kryteria, mianowicie:

1) kryterium przyrodnicze związane z pokryciem terenu roślinnością leśną (uprawami leśnymi), na którą składają się drzewa i krzewy oraz runo leśne ${ }^{3}$;

3) kryterium przestrzenne dotyczące konieczności zajmowania przez grunt zwartej powierzchni, co najmniej 0,10 ha;

4) kryterium przeznaczenia do produkcji leśnej, chyba że chodzi o lasy w rezerwatach przyrody i w parkach narodowych bądź wpisane do rejestru zabytków, które z istoty swej nie są przeznaczone do produkcji leśnej;

5) kryterium związku z gospodarką leśną ${ }^{4}$.

Podobne stanowisko, uwzględniające cztery kryteria konieczne, aby dany grunt mógł zostać uznany za las, zajmuje M.A. Zalewski. W jego opinii dla skonstruowania pojęcia lasu ustawodawca odwołuje się do

${ }^{2}$ B. Rakoczy, Komentarz do art. 3, w: idem, Ustawa o lasach. Komentarz, Warszawa 2011.

${ }^{3}$ Wskazać należy jednak, że przejściowe pozbawienie roślinności leśnej nie pozbawia gruntu przymiotu lasu, jeśli spełnione są pozostałe kryteria.

${ }^{4}$ W. Radecki, Ustawa o lasach. Komentarz, Warszawa 2008, s. 25. 
czterech cech gruntu, mianowicie: jego powierzchni, cech przyrodniczych, przeznaczenia oraz sposobu zagospodarowania ${ }^{5}$.

\subsection{Kryterium obszarowe}

Przechodząc do szczegółowego omówienia wyróżnionych w treści definicji lasu kryteriów, na wstępie należy wskazać, że podstawowym elementem definicji lasu jest odwołanie się do pojęcia gruntu. Ustawodawca wyraźnie bowiem wskazuje, że lasem jest określony grunt, dodatkowo określając jego minimalną powierzchnię na poziomie 0,10 ha.

Jak wskazuje B. Rakoczy, grunt oznacza fragment powierzchni ziemi $\mathrm{w}$ znaczeniu trójwymiarowym, który stanowi przedmiot określonych stosunków prawnych bądź to prawa prywatnego, bądź to prawa publicznego ${ }^{6}$. Pojęcie to, zdaniem tego autora, należy zatem wyraźnie odróżniać od pojęcia nieruchomości gruntowej. Także M.A. Zalewski akcentuje, że pojęcie lasu jest całkowicie niezależne i oderwane od pojęcia nieruchomości gruntowej; przywołany autor uważa przy tym, że

pojęcie własności lasu nie jest ścisłe i jest $\mathrm{w}$ istocie pewnym skrótem myślowym, który odnosi się do szczególnego przypadku stosunków prawa własności, których przedmiotem są: 1) nieruchomości leśne, to jest nieruchomości gruntowe spełniające równocześnie ustawowe przesłanki uznania za las, 2) nieruchomości, w skład których wchodzi las, to jest nieruchomości, w przypadku których jedynie pewna część gruntu spełnia przesłanki uznania za las, przy czym: a) grunty te są wydzielone geodezyjnie w odrębną działkę, b) grunty te nie stanowią oddzielnej działki ewidencyjnej ${ }^{7}$.

W nawiązaniu do przedstawionych rozważań rodzi się zatem uzasadnione pytanie, dotyczące zdefiniowanego w art. 3 pkt 1 u.l. kryterium obszarowego. Pojawiają się bowiem wątpliwości w zakresie tego, czy dana nieruchomość gruntowa może zostać uznana za las, jeżeli jej powierzchnia wynosi mniej niż 0,10 ha.

Odpowiedź na tak postawione pytanie musi być pozytywna, o ile spełnione są określone uwarunkowania natury faktycznej. Raz jeszcze należy bowiem podkreślić, że pojęcie lasu nie jest związane z pojęciem nieruchomości gruntowej, a jedynie z pojęciem gruntu. Klasyfikacja

${ }^{5}$ M.A. Zalewski, Przeniesienie własności lasu, w: Prawo rolne, problemy teorii i praktyki, pod red. R. Budzinowskiego, A. Zielińskiego, Kluczbork 2002, s. 191.

${ }^{6}$ B. Rakoczy, op. cit.

${ }^{7}$ M.A. Zalewski, op. cit., s. 191. 
nieruchomości o powierzchni mniejszej niż 0,10 ha jako lasu będzie zatem dopuszczalna, jeżeli będzie ona bezpośrednio przylegać do terenu sąsiedniej działki lub działek, który także pokryty jest roślinnością i runem leśnym, a łączna powierzchnia całego obszaru zalesionego wyniesie co najmniej 0,10 ha. Co istotne, stanowisko takie znajduje potwierdzenie w orzecznictwie sądowo-administracyjnym. W wyroku z 7 czerwca 2005 r. Wojewódzki Sąd Administracyjny (WSA) w Białymstoku przesądził, że jeżeli działka sama w sobie ma powierzchnię mniejszą niż 0,10 ha, to nie pozbawia jej to statusu gruntu leśnego w sytuacji graniczenia $\mathrm{z}$ innymi gruntami leśnymi, tworzącymi łącznie zwartą powierzchnię ponad $0,10 \mathrm{ha}^{8}$. Pogląd taki powtarzany był także w kolejnych latach w orzeczeniach innych wojewódzkich sądów administracyjnych ${ }^{9}$.

Niezwiązanie pojęcia lasu ze stosunkami właścicielskimi dotyczącymi danej nieruchomości gruntowej podkreślił także Naczelny Sąd Administracyjny (NSA) w wyroku z 2 października 2015 r., w którym wyraźnie zaznaczył, że

przepisy komentowanej ustawy [z dnia 28 września 1991 r. o lasach] nie dają podstaw, aby przyjąć, że lasem jest wydzielony grunt jako nieruchomość gruntowa o przypisanym do danego podmiotu stosunku prawnym o charakterze majątkowym. Innymi słowy [przyjmując rozumowanie przeciwne] o zakresie rozumienia tego pojęcia decydowałoby uprawnienie o charakterze cywilnym. W ocenie Sądu definicja lasu pozostaje bez związku z pojęciem nieruchomości gruntowej oraz uprawnień majątkowych przysługujących do tej nieruchomości ${ }^{10}$.

Podsumowując przedstawione powyżej rozważania dotyczące kryterium obszarowego, należy zatem stwierdzić, że nawet w przypadku kiedy obszar danej nieruchomości gruntowej pokryty roślinnością leśną ma powierzchnię mniejszą niż ustawowo wymagane 0,10 ha, może być on uznany za las w rozumieniu art. 3 u.l., jeżeli bezpośrednio łączy się z innym zalesionym terenem niewchodzącym w skład tej samej nieruchomości gruntowej i łączna powierzchnia obu obszarów wynosi co najmniej 0,10 ha.

${ }^{8}$ Wyrok WSA w Białymstoku z 7 VI 2005 r., sygn. II SA/Bk 130/05, LEX nr 173757.

${ }^{9}$ Warto w tym miejscu przywołać m.in.: wyrok WSA w Łodzi z 10 XII 2010 r., sygn. II SA/Łd 1023/10, LEX nr 755678; wyrok WSA w Lublinie z 8 X 2013 r., sygn. II SA/ Lu 295/13, LEX nr 1387395; wyrok WSA w Warszawie z 18 VI 2014 r., sygn. IV SA/Wa 877/14, LEX nr 1562903.

${ }^{10}$ Wyrok NSA w Warszawie z 2 X 2015 r., sygn. II OSK 308/14, LEX nr 2002652. 


\subsection{Przesłanki funkcjonalne}

Niewątpliwie, kwestia związku pojęcia lasu z pojęciami gruntu oraz nieruchomości gruntowej, a co za tym idzie, wątpliwości dotyczące kryterium obszarowego omówione $\mathrm{w}$ punkcie poprzednim mają niezwykle istotne znaczenie dla możliwości klasyfikowania określonych obszarów jako lasów. Rozwiązanie owych problemów, przedstawione powyżej, ma jednak ugruntowane poparcie zarówno w doktrynie, jak i orzecznictwie sądowoadministracyjnym. Zupełnie inaczej sytuacja ma się natomiast w przypadku kontrowersji dotyczących konieczności każdorazowego spełniania przez grunt mający być zaklasyfikowany jako las przesłanek funkcjonalnych określonych w art. 3 pkt 1 lit. a-c u.l. Wokół tego zagadnienia pojawiły się bowiem znaczne rozbieżności poglądów, które $\mathrm{w}$ praktyce doprowadziły do ukształtowania w systemie prawnym dwóch odrębnych linii orzeczniczych. Zgodnie z pierwszą z nich, którą umownie nazwać można "liberalną", grunty pokryte roślinnością leśną zawsze należy uznać za lasy, o ile zostało spełnione kryterium obszarowe, natomiast przesłanki funkcjonalne dotyczą jedynie gruntów przejściowo pozbawionych roślinności leśnej. Druga, „restrykcyjna”, linia orzecznicza wskazuje natomiast, iż przesłanki funkcjonalne muszą być spełniane przez dany grunt każdorazowo niezależnie od tego, czy jest on pokryty roślinnością leśną, czy też przejściowo jej pozbawiony.

\subsection{1. "Liberalna" linia orzecznicza}

Jako przykład pierwszej ze wskazanych linii orzeczniczych w orzecznictwie sądów administracyjnych można wskazać m.in. wyrok WSA w Poznaniu z 16 kwietnia 2014 r., w którym stwierdzono, że

za las należy uznać zatem każdy grunt o zwartej powierzchni co najmniej 0,10 ha, pokryty roślinnością leśną (uprawami leśnymi) - drzewami i krzewami oraz runem leśnym, który nie spełnia żadnego dodatkowego kryterium $\mathrm{z}$ art. 3 pkt 1 lit. a, b i c tej ustawy (nie jest przeznaczony do produkcji leśnej, nie stanowi rezerwatu przyrody ani nie został wpisany do rejestru zabytków). Dodatkowe kryteria dotyczą bowiem tylko gruntów o obszarze co najmniej 0,10 ha przejściowo pozbawionych roślinności leśnej ${ }^{11}$.

${ }^{11}$ Wyrok WSA w Poznaniu z 16 IV 2014 r., sygn. II SA/Po 1301/13, LEX nr 1500382. Co ważne, podgląd ten nie jest odosobniony, tożsame stanowisko zajmowały w swoim 
Co więcej, w wyroku z 9 grudnia 2016 r. WSA w Krakowie podkreślił, że pogląd o braku konieczności każdorazowego wypełniania przez dany grunt mający być zaklasyfikowany jako las kryteriów funkcjonalnych należy uznać za ugruntowany ${ }^{12}$.

Takie „liberalne" rozumienie pojęcia lasu na gruncie art. 3 u.l. wywodzi się z konsekwentnego orzecznictwa prezentowanego $w$ tym zakresie przez Sąd Najwyższy (SN). Za fundamentalny należy tu uznać wyrok SN z 28 stycznia 2009 r., w którym sąd już na wstępie zasygnalizował, że sporna jest wykładnia art. 3 pkt 1 u.l. ${ }^{13} \mathrm{~W}$ ocenie SN

wykładnia gramatyczna tego przepisu nie prowadzi do jednoznacznych wniosków, aczkolwiek przyjęcie poglądu, że lasem jest tylko grunt o zwartej powierzchni co najmniej 10 arów, pokryty roślinnością leśna, o ile spełnia jedno z kryteriów wymienionych przed literami a, b lub c, prowadzi a contrario do wniosku, że nie byłaby lasem np. nieruchomość o obszarze 10 ha, pokryta roślinnością leśną, krzewami oraz runem leśnym, jeśli nie byłaby przeznaczona do produkcji leśnej, nie stanowiłaby rezerwatu przyrody lub nie byłaby wpisana do rejestru zabytków ${ }^{14}$.

Zdaniem Sądu Najwyższego taki wniosek byłby trudny do zaakceptowania. Co istotne, w przywołanym orzeczeniu sąd, dokonując analizy przepisów Ustawy z dnia 17 maja 1989 r. Prawo geodezyjne i kartograficzne oraz wydanego na jej podstawie Rozporządzenia Ministra Rozwoju Regionalnego i Budownictwa z dnia 29 czerwca 2001 r. w sprawie ewidencji gruntów i budynków, wskazał, że na gruncie tych dwóch aktów prawnych podstawą rozróżnienia między lasem (jako gruntem pokrytym roślinnością leśną) a gruntami zadrzewionymi i zakrzewionymi (jako również gruntem pokrytym roślinnością

orzecznictwie również inne wojewódzkie sądy administracyjne. Zob.: wyrok WSA w Białymstoku z 5 IV 2012 r., sygn. II SA/Bk 132/12, LEX nr 1145729; wyrok WSA w Krakowie z 2 XII 2013 r., sygn. II SA/Kr 1501/12, LEX nr 1495344; wyrok WSA w Poznaniu z 11 VII 2013 r., sygn. II SA/Po 343/13, LEX nr 1513456; wyrok WSA w Warszawie z 25 V 2011 r., sygn. IV SA/Wa 547/11, LEX nr 1100718; wyrok WSA w Łodzi z 6 V 2014 r., sygn. II SA/Łd 161/14, LEX nr 1531537; nieprawomocny wyrok WSA w Gdańsku z 6 VIII 2015 r., sygn. II SA/Gd 215/15, LEX nr 1790658; nieprawomocny wyrok WSA w Gdańsku z 7 XII 2016 r., sygn. II SA/Gd 481/16, LEX nr 2173269.

${ }_{12}$ Wyrok WSA w Krakowie z 9 XII 2016 r., sygn. II SA/Kr 1138/16, LEX nr 2190123.

${ }^{13}$ W ocenie Sądu Najwyższego sporny charakter wykładni tego przepisu sprowadza się właśnie do tego, czy za las może być uznany każdy grunt o zwartej powierzchni co najmniej 0,10 ha pokryty roślinnością leśną, drzewami i krzewami oraz runem leśnym, czy też grunt taki musi nadto spełniać jedno z kryteriów funkcjonalnych.

${ }^{14}$ Wyrok SN z 28 I 2009 r., sygn. IV CSK 353/08, Orzecznictwo Sądu Najwyższego Izba Cywilna - Zbiór Dodatkowy 2009, nr 4, poz. 99. 
leśną) jest wyłącznie kryterium obszarowe. Lasem jest zatem grunt pokryty roślinnością leśną o obszarze zwartym co najmniej 10 arów, zaś gruntami zadrzewionymi i zakrzewionymi sa grunty pokryte roślinnością leśną o obszarze poniżej 10 arów. Sąd, odpowiadając na pytanie, czy to wynikające $z$ treści rozporządzenia w sprawie ewidencji rozróżnienie pojęcia lasu i terenów zadrzewionych i zakrzewionych jest miarodajne dla wykładni art. 3 pkt 1 u.l. (ze względu na to, że jest to akt prawny niższego rzędu, a nadto akt wykonawczy do innej ustawy, tj. ustawy Prawo geodezyjne i kartograficzne), stwierdził, że jest to istotna wskazówka przy wykładni art. 3 pkt 1 u.l. Jak bowiem zaznaczył Sąd Najwyższy,

jeśli zakłada się spójność systemu prawnego i racjonalność ustawodawcy, to należy uznać, że ustawa i rozporządzenie (co prawda do innej ustawy, lecz odwołując się wprost do legalnej definicji lasu w ustawie o lasach) wchodzą w skład systemu prawnego pozbawionego luk i sprzeczności.

W konsekwencji, zdaniem SN, należy przyjąć, że w świetle art. 3 pkt 1 u.l. za las należy uznać także grunt o zwartej powierzchni co najmniej 0,10 ha pokryty roślinnością leśną (uprawami leśnymi), drzewami i krzewami oraz runem leśnym, który nie spełnia żadnego dodatkowego kryterium $z$ art. 3 pkt 1 lit. a, b i c u.l. (nie jest przeznaczony do produkcji leśnej, nie stanowi rezerwatu przyrody ani nie został wpisany do rejestru zabytków). Dodatkowe kryteria dotyczą zaś gruntów o obszarze co najmniej 0,10 ha przejściowo pozbawionych roślinności leśnej ${ }^{15}$.

\subsubsection{Restrykcyjna linia orzecznicza}

Wskazać należy jednak, że w orzecznictwie sądowoadministracyjnym, w tym w orzeczeniach wydawanych przez Naczelny Sąd Administracyjny, nierzadko spotkać się można także z wykładnią art. 3 u.l., zgodnie z którą do zakwalifikowania danego gruntu jako lasu konieczne jest spełnianie przez niego każdorazowo jednej z przesłanek funkcjonalnych.

Jako przykład wskazać można wyrok WSA w Gdańsku z 28 listopada 2007 r. W przedmiotowym wyroku sąd orzekł, że w myśl art. 3 ust. 1 u.l.

${ }^{15}$ Należy przy tym podkreślić, że zaprezentowane stanowisko Sądu Najwyższego nie ma charakteru jednostkowego, bowiem przychylono się do niego także w wyroku SN z 28 I 2010 r., sygn. I CSK 258/09, LEX nr 565990, oraz w postanowieniu SN z 20 IX 2012 r., sygn. IV CSK 41/12, LEX nr 1232472. 
o tym, czy grunt o powierzchni przekraczającej 0,10 ha ma charakter lasu, decyduje nie sam rodzaj znajdujących się na nim upraw, rodzaj drzewostanu, lecz przeznaczenie go do produkcji leśnej lub związanie z gospodarką leśną ${ }^{16}$. Zaznaczyć należy jednak, że wyrok ten wydany został przed fundamentalnym dla kwestii wykładni przepisu art. 3 u.l. wyrokiem Sądu Najwyższego w sprawie o sygn. IV CSK 353/08.

Orzeczenia przyjmujące "restrykcyjną" wykładnię przepisu art. 3 u.l. były jednak (i są nadal) wydawane także już po ukształtowaniu się liberalnego sposobu wykładni tego przepisu w judykatach Sądu Najwyższego. Jako orzeczenie fundamentalne dla funkcjonowania takiej linii orzeczniczej należy wskazać wyrok NSA z 23 kwietnia 2013 r. Wyrok ten wydany został już po przywoływanych w poprzednim punkcie orzeczeniach Sądu Najwyższego opowiadających się za liberalną wykładnią art. 3 u.l. W przedmiotowym orzeczeniu Naczelny Sąd Administracyjny uznał jednak, odmiennie niż Sąd Najwyższy, iż

w zakresie normatywnym istotnym dla ustalenia, że grunt jest lasem nie tylko w znaczeniu przyrodniczym, ale także prawnym, konieczne jest spełnienie nie tylko kryterium przyrodniczego (pokrycie roślinnością leśną) i kryterium przestrzennego (zwarta powierzchnia co najmniej 0,10 ha), lecz także kryterium przeznaczenia (do produkcji leśnej; lit. a punktu 1 art. 3) bądź jednej z pozostałych przesłanek $z$ lit. $b$ (grunt stanowiący rezerwat przyrody lub wchodzący w skład parku narodowego) czy lit. c (grunt wpisany do rejestru zabytków) ${ }^{17}$.

W związku z taką wykładnią przepisu art. 3 u.l. NSA wskazał, że grunt, który co prawda spełnia kryterium przyrodnicze i obszarowe, nie wypełnia jednak żadnej z przesłanek funkcjonalnych, nie może zostać uznany za las w znaczeniu prawnym.

Taka, „restrykcyjna”, wykładnia omawianego przepisu, za którą jednoznacznie opowiedział się NSA w cytowanym powyżej wyroku z 23 kwietnia 2013 r., została także przyjęta w wielu innych wyrokach tego sądu ${ }^{18}$ Jak jednak wskazano w poprzednim punkcie niniejszego opracowania, wojewódzkie sądy administracyjnie w licznych orzeczeniach chętnie powoływały się na wykładnię przepisu art. 3 u.l. zaproponowaną przez

${ }^{16}$ Wyrok WSA w Gdańsku z 28 XI 2007 r., sygn. II SA/Gd 601/07, LEX nr 436291.

17 Wyrok NSA z 23 IV 2013 r., sygn. I OSK 1983/11, LEX nr 1336348.

${ }_{18}$ Zob. m.in.: wyrok NSA z 12 IX 2012 r., sygn. I OSK 1260/11, LEX nr 1218350; wyrok NSA z 23 V 2013 r., sygn. II OSK 215/12, LEX nr 1559533; przywoływany już wyrok NSA z 2 X 2015 r., sygn. II OSK 308/14; wyrok NSA z 8 II 2017 r., sygn. II OSK 686/16, LEX nr 2282130; wyrok NSA z 8 II 2017 r., sygn. II OSK 1524/15, LEX nr 2282129. 
Sąd Najwyższy ${ }^{19}$. Z kolei wykładnia "restrykcyjna” jest, jak się wydaje, dominująca w orzecznictwie NSA ${ }^{20}$.

Pokrótce podsumowując rozważania w tym punkcie, należy raz jeszcze podkreślić, że orzecznictwo dotyczące przesłanek funkcjonalnych zawartych w definicji lasu jest dalece niejednolite i de facto równolegle funkcjonują w tym obszarze dwie linie orzecznicze wyrażające całkowicie przeciwstawne poglądy. Próbując podjąć się oceny wskazanych wyżej stanowisk judykatury, należy zauważyć, że z czysto językowego punktu widzenia bardziej zasadny wydaje się pogląd "restrykcyjny". Sformułowanie przepisu art. 3 u.l. nie pozwala bowiem, na gruncie wykładni językowej, różnicować przesłanek uznania za las w odniesieniu do gruntów pokrytych roślinnością leśną i gruntów przejściowo jej pozbawionych. Należy jednak pamiętać, że zgodnie z derywacyjną koncepcją wykładni prawa nawet jednoznaczny wynik wykładni językowej może zostać podważony w rezultacie dokonania wykładni funkcjonalnej. W ocenie autorów taka sytuacja zachodzi właśnie w omawianym przypadku, w którym, w efekcie dokonania wykładni funkcjonalnej omawianego przepisu, należałoby dopuścić stosowanie przesłanek funkcjonalnych jedynie w przypadku gruntów przejściowo pozbawionych roślinności leśnej. Taka "liberalna” wykładnia art. 3 u.l. wydaje się bowiem bardziej uzasadniona $\mathrm{z}$ aksjologicznego punktu widzenia. Opowiadając się za takim stanowiskiem, przywołać można cytowany już fragment wyroku SN z 28 stycznia 2009 r., sygn. IV CSK 353/08, wskazujący, że przyjęcie restrykcyjnej drogi wykładni definicji lasu mogłoby prowadzić do trudnej do zaakceptowania sytuacji, w której za las nie można by uznać nieruchomości o obszarze 10 ha pokrytej roślinnością leśna, krzewami oraz runem leśnym, jeśli nie byłaby przeznaczona do produkcji leśnej, nie stanowiłaby rezerwatu przyrody lub nie byłaby wpisana do rejestru zabytków.

\footnotetext{
${ }^{19}$ Należy w tym miejscu wskazać także wyroki, w których wojewódzkie sądy administracyjne przyjmują "restrykcyjną" wykładnię art. 3 u.l., jak np.: wyrok WSA w Bydgoszczy z 23 III 2015 r., sygn. II SA/Bd 901/14, LEX nr 1852670; wyrok WSA w Warszawie z 18 III 2015 r., sygn. IV SA/Wa 2525/14, LEX nr 1975040; wyrok WSA w Gdańsku z 20 IV 2016 r., sygn. II SA/Gd 708/15, LEX nr 2045509. Stanowią one jednak mniejszość orzeczeń wojewódzkich sądów administracyjnych dotyczących tej problematyki.

${ }^{20}$ Od tej reguły zdarzają się oczywiście wyjątki. Wskazać trzeba bowiem, że np. w wyroku z 9 IX 2015 r., sygn. II OSK 95/14, LEX nr 1987321, NSA przyjął "liberalną" wykładnię przepisu art. 3 u.l., przywołując w treści uzasadnienia twierdzenia z cytowanego wyroku SN z 28 I 2009 r., sygn. IV CSK 353/08.
} 


\section{Znaczenie wpisu do ewidencji gruntów i budynków}

Kolejnym problemem, który powstaje przy omawianiu prawnej definicji lasu, jest kwestia doniosłości oznaczenia danego terenu w ewidencji gruntów i budynków. Na gruncie tego zagadnienia pojawiają się bowiem dwa pytania. Po pierwsze, czy wpis w ewidencji określający dany teren jako las przesądza o jego leśnym charakterze niezależnie od występujących uwarunkowań faktycznych. Po drugie, wskazać należy, że podobne wątpliwości pojawiają się także w sytuacji odwrotnej, trzeba bowiem rozważyć, czy możliwe jest uznanie za las gruntu, który faktycznie spełnia wymagania określone w art. 3 u.l., jednak w ewidencji gruntów i budynków zaklasyfikowany jest w inny sposób, np. jako grunt orny.

Na wstępie rozważań nad tym zagadnieniem należy nadmienić, że teoretycznie nie powinny istnieć rozbieżności pomiędzy wpisem do ewidencji a stanem faktycznym danej nieruchomości mającej charakter leśny. Zgodnie bowiem z załącznikiem nr 6 do Rozporządzenia Ministra Rozwoju Regionalnego i Budownictwa z dnia 29 marca 2001 r. w sprawie ewidencji gruntów i budynków ${ }^{21}$ jako tereny leśne, oznaczone symbolem „Ls” w ewidencji gruntów i budynków, klasyfikować należy grunty, które wypełniają definicję lasu zawartą w art. 3 u.l.

W praktyce jednak stan prawny danego gruntu ujęty w ewidencji często odbiega od występującego na nim stanu faktycznego. Może to być spowodowane $z$ jednej strony niezgłoszeniem przez właściciela zmian do ewidencji, np. w przypadku usunięcia zadrzewienia $\mathrm{z}$ danego terenu, z drugiej zaś pokrywaniem nieużywanych przez wiele lat terenów, np. o przeznaczeniu rolniczym, samosiejkami drzew. Dlatego też w praktyce często pojawia się problem, czy decydujący o klasyfikacji danego gruntu jako lasu ma być wpis do ewidencji, czy też występujący w danej sprawie stan faktyczny.

\subsection{Decydujący charakter wpisu w ewidencji}

W doktrynie dominuje pogląd, że decydujący charakter powinien mieć w takiej sytuacji wpis w ewidencji gruntów i budynków. Takie stanowisko zajmuje zarówno W. Radecki, który stwierdza, iż „w praktyce o kwalifikacji gruntu jako lasu w oparciu o kryterium przeznaczenia

\footnotetext{
${ }^{21}$ Tekst jedn. Dz.U. 2015, poz. 542 ze zm.
} 
rozstrzygają dane z ewidencji gruntów prowadzonej na podstawie ustawy z 17 maja 1989 r. prawo geodezyjne i kartograficzne"22, jak i K. Gruszecki, zdaniem którego „najprostszym do wykazania dowodem świadczącym o tym, czy w konkretnym przypadku mamy do czynienia $z$ lasem, będzie wypis z ewidencji gruntów" ${ }^{\prime 23}$.

W praktyce orzeczniczej sądów administracyjnych poglądy w tej kwestii nie są jednak jednolite. Jako przykład orzeczenia aprobującego przywołane wyżej poglądy doktryny można wskazać wyrok WSA w Bydgoszczy z 25 marca 2015 r., zapadły na gruncie sporu dotyczącego uchwały w sprawie miejscowego planu zagospodarowania przestrzennego, w którym sąd jednoznacznie wskazuje, iż

stosowny zapis w ewidencji gruntów i budynków stanowi urzędowe potwierdzenie, że dany obszar jest lasem czy gruntem rolnym. Tego dowodu nie mogą samodzielnie kwestionować organy administracyjne czy też Sąd i w sposób odmienny sklasyfikować danego obszaru ${ }^{24}$.

Także Naczelny Sąd Administracyjny w wyroku z 22 stycznia 2014 r., dotyczącym odmowy ustalenia warunków zabudowy, stwierdził, że

ustalenie, iż część terenu inwestycyjnego jest to teren leśny, ma odzwierciedlenie w ewidencji gruntów, zaś faktyczne wykorzystanie czy aktualny stan tego terenu nie zmienia tej kwalifikacji, czego oczekiwałby autor skargi kasacyjnej, ponieważ zapisy ewidencji gruntów są dla organów wiążące, a w konsekwencji organy nie mają kompetencji do samodzielnego ustalania rzeczywistego sposobu wykorzystywania terenu ${ }^{25}$.

Podstawę stanowiska wyrażanego w powołanych wyżej orzeczeniach sądów administracyjnych stanowi treść art. 21 ust. 1 Ustawy z dnia 17 maja 1989 r. Prawo geodezyjne i kartograficzne ${ }^{26}$. Zgodnie z tym przepisem podstawę planowania gospodarczego, planowania przestrzennego, wymiaru podatków i świadczeń, oznaczania nieruchomości

${ }^{22}$ W. Radecki, op. cit., s. 17.

${ }^{23}$ K. Gruszecki, Zezwolenia na usunięcie drzew i krzewów, Wrocław 2011, s. 107.

${ }^{24}$ Wyrok WSA w Bydgoszczy z 25 III 2015 r., sygn. II SA/Bd 901/14, LEX nr 1852670. Podobne stanowiska zostały zaprezentowane także np. w: wyroku WSA w Warszawie z 8 III 2011 r., sygn. I SA/Wa 1745/10, LEX nr 1127355, zapadłym na gruncie przepisów Ustawy z dnia 19 X 1991 r. o gospodarowaniu nieruchomościami rolnymi Skarbu Państwa oraz o zmianie niektórych ustaw (tekst jedn. Dz.U. 2015, poz. 1014 ze zm.), wyroku WSA w Łodzi z 6 V 2014 r., sygn. II SA/Łd 161/14, LEX nr 1531537, dotyczącym decyzji w sprawie ustalenia warunków zabudowy, czy też wyroku WSA w Warszawie z 30 XI 2016 r., sygn. IV SA/Wa 1815/16, który dotyczył decyzji o warunkach zabudowy.

${ }^{25}$ Wyrok NSA z 22 I 2014 r., sygn. II OSK 1952/12, LEX nr 1765814.

${ }^{26}$ Tekst jedn. Dz.U. 2016, poz. 1629 ze zm. 
w księgach wieczystych, statystyki publicznej, gospodarki nieruchomościami oraz ewidencji gospodarstw rolnych stanowią dane zawarte w ewidencji gruntów i budynków. Z przepisu tego sądy administracyjne wywodza, że organy rozstrzygające w sprawach z zakresu wskazanego $\mathrm{w}$ jego treści są związane danymi zawartymi w ewidencji gruntów, zatem także danymi dotyczącymi charakteru danego gruntu.

Warto jednak zaznaczyć, że przepis ten nie stanowi wprost, iż dane zawarte w ewidencji gruntów i budynków mają charakter wiążący, ale jedynie przesądza o tym, że mają one stanowić podstawę działań organów administracji w określonych kategoriach spraw. Wydaje się zatem, że nie sposób przyjąć, iż art. 21 ust. 1 Ustawy z dnia 17 maja 1989 r. Prawo geodezyjne i kartograficzne przesądza o związaniu organów administracji treścią wpisów do ewidencji gruntów i budynków. Bardziej zasadna wydaje się mniej restrykcyjna wykładnia powyższego przepisu, zgodnie z którą ustanawia on jedynie swoiste domniemanie, że dany grunt faktycznie ma cechy określone w ewidencji, przy czym możliwe jest, oczywiście, przedstawienie dowodów obalających takie założenie, a organ zobligowany jest skonfrontować dane zawarte $\mathrm{w}$ ewidencji z rzeczywistym stanem danej nieruchomości, działając zgodnie z wyrażoną w art. 77 \& 1 Ustawy z dnia 14 czerwca 1960 r. Kodeks postępowania administracyjnego ${ }^{27}$ zasadą wyczerpującego zebrania i rozpatrzenia całego materiału dowodowego.

\subsection{Wpis w ewidencji jako jeden z elementów umożliwiających ustalenie faktycznego charakteru gruntu}

Wskazać należy, że w praktyce orzeczniczej sądów administracyjnych występuje również pogląd stwierdzający, że wpis w ewidencji gruntów i budynków nie ma decydującego charakteru dla klasyfikacji danego gruntu jako lasu, a najważniejsze są w tym zakresie ustalenia faktyczne. Przywołać trzeba w tym miejscu chociażby wyrok NSA z 3 września 2015 r., w którym sąd wskazuje, że

w świetle przepisów ustawy o ochronie gruntów rolnych i leśnych zapisy w ewidencji gruntów nie mają decydującego znaczenia dla dokonania oceny, czy dany grunt jest gruntem leśnym, gdyż o tym decyduje wyłącznie to, czy spełnia on przesłanki $z$ art. 3 ustawy o lasach $\mathrm{w}$ zw. $\mathrm{z}$ art. 2 ust. 2 pkt 1 ustawy o ochronie

\footnotetext{
${ }^{27}$ Tekst jedn. Dz.U. 2016, poz. 23 ze zm.
} 
gruntów rolnych i leśnych albo pozostałe przesłanki wymienione w art. 2 ust. 2 pkt 2 lub 3 ustawy o ochronie gruntów rolnych i leśnych ${ }^{28}$.

Na tożsamym stanowisku stanął także WSA w Krakowie w wyroku z 9 maja 2016 r., w którym wskazał, że

dane zawarte w ewidencji gruntów i budynków nie mają przesądzającego znaczenia dla ustalenia, czy dany grunt jest np. lasem. Jak wynika z powołanej definicji lasu z ustawy o lasach, w żadnym jej elemencie ustawodawca nie odwołał się do zapisów zawartych w ewidencji gruntów. Ustawodawca nie uczynił tego także w ustawie o ochronie gruntów rolnych i leśnych ${ }^{29}$.

Co istotne, w treści tego orzeczenia sąd skonfrontował obecnie obowiązujący stan prawny ze stanem prawnym występującym wcześniej na gruncie Ustawy z dnia 26 marca 1982 r. o ochronie gruntów rolnych i leśnych ${ }^{30}$, której art. 2 ust. 2 pkt 1 wprost wskazywał, że gruntami leśnymi były grunty określone w ewidencji gruntów jako lasy. W związku z tym sąd wyraźnie podkreślił, iż

w poprzednio obowiązującym stanie prawnym zapis w ewidencji gruntu miał znaczenie decydujące dla przyjęcia, że dany grunt jest gruntem leśnym, i zarazem stanowił element definicji gruntu leśnego. W obecnym stanie prawnym brak podstaw do tak zdecydowanego wnioskü ${ }^{31}$.

Podobne stanowisko zajął również WSA we Wrocławiu w wyroku z 7 października 2010 r., w którym nie tylko zaznaczono, że zapisy w ewidencji nie zawsze są na bieżąco aktualizowane, ale także podkreślono (niejako w opozycji do zaprezentowanych w poprzednim punkcie poglądów przedstawicieli doktryny), iż

ewidencja jest jedynie zbiorem (rejestrem) informacji o określonych okolicznościach faktycznych i prawnych, zwanych danymi ewidencyjnymi. W tym znaczeniu ewidencja gruntu ma znaczenie jedynie informacyjno-techniczne, odzwierciedlające określony bezspornie stan faktyczny i prawny ${ }^{32}$.

${ }^{28}$ Wyrok NSA z 3 IX 2015 r., sygn. II OSK 64/14, LEX nr 1918770.

${ }^{29}$ Wyrok WSA w Krakowie z 9 V 2016 r., sygn. II SA/Kr 310/16, LEX nr 2043146.

${ }^{30}$ Dz.U. 1982 Nr 11, poz. 79 ze zm.

${ }^{31}$ Wyrok WSA w Krakowie z 9 V 2016 r., sygn. II SA/Kr 310/16, LEX nr 2043146. Należy zauważyć, że stanowisko takie nie jest odosobnione, a analogiczny pogląd został wyrażony w wyroku WSA w Łodzi z 21 X 2015 r., sygn. II SA/Łd 538/15, LEX nr 1930266, oraz w wyroku WSA w Gliwicach z 30 VII 2014 r., sygn. II SA/Gl 335/14, LEX nr 1519827.

${ }^{32}$ Wyrok WSA we Wrocławiu z 7 X 2010 r., sygn. II SA/Wr 326/10, LEX nr 755562. W zakresie charakteru prawnego ewidencji gruntów i budynków obszernie wypowiedział się także NSA w wyroku z 15 V 2014 r., sygn. I OSK 2566/12, LEX nr 1586061, w którym wskazał m.in., że „dane zawarte w ewidencji gruntów i budynków mają charakter 
W ocenie tego sądu brak oznaczenia w ewidencji, że dany użytek gruntowy jest lasem, nie zmienia jego faktycznego charakteru. Wyrok ten zapadł na gruncie sporu o wydanie zezwolenia na usunięcie drzew. Sąd stwierdził, że wpis w ewidencji ma charakter jedynie pomocniczy dla ustalenia oznaczenia użytku. Jednocześnie należy zauważyć, że WSA podkreślił przy tym, iż wprawdzie w większości przypadków wpis do ewidencji będzie stanowił miarodajny dowód dla ustalenia charakteru danego gruntu, jednakże w przypadku rozbieżności danych ewidencyjnych ze stanem faktycznym decyduje rzeczywisty stan gruntu ${ }^{33}$.

Na jedynie informacyjną funkcję zapisów w ewidencji gruntów i budynków zwrócił także uwagę Sąd Najwyższy, który w obszernie cytowanym już wyroku z dnia 28 stycznia 2009 r., sygn. IV CSK 353/08, stwierdził, że

zapisy w ewidencji mają - w tym zakresie [charakteru danego terenu] - funkcję informacyjną. Zapisy w ewidencji mają być na bieżąco aktualizowane, co jednak nie zawsze następuje. Wreszcie wskazać należy, że w ustawie o lasach nie ma odpowiednika art. 92 ust. 2 ustawy o gospodarce nieruchomościami, który przy braku planów miejscowych zezwala posłużyć się formułą wykorzystywania gruntu na określony cel według zapisu w ewidencji. Prowadzi to do wniosku, że w okolicznościach niniejszej sprawy nie można przypisać oznaczeniu w ewidencji spornej nieruchomości jako "tereny różne" rozstrzygającego znaczenia. Przeciwnie, decyduje rzeczywisty stan gruntu, rzeczywisty cel, na który był wykorzystywany w chwili zawarcia kwestionowanej umowy.

Z kolei w wyroku WSA w Krakowie z 6 listopada 2013 r. wyraźnie zaakcentowano, że „samo oznaczenie przeznaczenia gruntów w ewidencji gruntów nie jest decydujące w każdej sytuacji dla określenia przeznaczenia gruntu", zarazem wskazując jednak, iż "nawet jeśli zapisy z ewidencji gruntów mogą nie mieć rozstrzygającego znaczenia dla uznania, czy przedmiotowa działka stanowi grunt leśny, to danych z ewidencji nie można pominąć, w szczególności gdy znajdują potwierdzenie w innych dokumentach i faktach", oraz podkreślając, iż "oznaczenie to nie może być nieuwzględnione, gdy wraz z innymi okolicznościami

informacyjny, a sam rejestr ewidencji gruntów jest wyłącznie odzwierciedleniem aktualnego stanu prawnego dotyczącego danej nieruchomości. Ma on charakter deklaratoryjny, a nie konstytutywny, co oznacza, że nie tworzy nowego stanu prawnego nieruchomości, a jedynie potwierdza stan faktyczny".

${ }^{33}$ Analogiczny pogląd został zaprezentowany w wielu orzeczeniach WSA w Krakowie, m.in. w wyroku z 31 I 2012 r., sygn. II SA/Kr 1051/11, LEX nr 1113917, czy też w wyroku z 2 XII 2013 r., sygn. II SA/Kr 1501/12, LEX nr 1495344. 
wskazuje, czy mamy do czynienia z gruntem rolnym (np. ornym) czy z gruntem leśnym" 34 .

Sąd w orzeczeniu tym wyraźnie wskazuje zatem na konieczność kompleksowej oceny zarówno stanu prawnego danego gruntu ujawnionego w ewidencji gruntów i budynków, jak i stanu faktycznie występującego na gruncie w czasie rozpatrywania danej sprawy. Dopiero bowiem taka kompleksowa ocena może stanowić podstawę do dokonania prawidłowej kwalifikacji danego gruntu.

W tym kontekście warto odnieść się także do problemu poruszanego pod koniec poprzedniego punktu niniejszego artykułu, a dotyczącego przepisu art. 21 ust. 1 Ustawy z dnia 17 maja 1989 r. Prawo geodezyjne i kartograficzne oraz związanego z nim stanowiska wyrażanego przez część sądów administracyjnych w zakresie związania organów administracji treścią danych zawartych w ewidencji gruntów i budynków. Warto w tym miejscu powołać wyrok WSA w Gliwicach z 30 lipca 2014 r., w którym WSA wskazał wyraźnie, że
powołanego przepisu [art. 21 ust. 1 Ustawy z dnia 17 maja 1989 r. Prawo geodezyjne i kartograficzne] nie należy jednak rozumieć w sposób przyjęty przez orzekające $\mathrm{w}$ sprawie organy [tj. że przez las należy rozumieć jedynie grunty charakteryzujące się tego rodzaju użytkiem gruntowym wskazanym w ewidencji gruntów i budynków]. Z żadnego przepisu prawa nie wynika bo- wiem, aby wpis w ewidencji gruntów dotyczący rodzaju użytku gruntowego był rozstrzygający w postępowaniu w przedmiocie wydania decyzji o warun- kach zabudowy i zagospodarowania terenu. Ewidencja gruntów i budynków stanowi bowiem specjalnie prowadzony zbiór informacji o gruntach, który spełnia jedynie funkcję rejestrującą stany faktyczne i prawne odnoszące się do poszczególnych gruntów ${ }^{35}$.

Na poparcie postawionej w poprzednim punkcie tezy, że art. 21 ust. 1 Ustawy z dnia 17 maja 1989 r. Prawo geodezyjne i kartograficzne $w$ istocie ustanawia jedynie swoiste domniemanie, iż dane zawarte w ewidencji gruntów i budynków odpowiadają rzeczywistemu charakterowi danego gruntu, możliwe jest jednak przeprowadzanie dowodów wykazujących odmienny stan faktyczny, warto przywołać także wyrok

${ }^{34}$ Wyrok WSA w Krakowie z 6 XI 2013 r., sygn. II SA/Kr 877/13, LEX nr 1398401. Wyrok ten został, co prawda, uchylony wyrokiem NSA z 10 XI 2015 r., sygn. II OSK 536/14, LEX nr 1990852, w związku z wydaniem w toku postępowania kasacyjnego przez Trybunał Konstytucyjny wyroku z 1 XI 2014 r., sygn. SK 6/12, Dz.U. poz. 926. Z treści uzasadnienia wyroku NSA wynika jednak, że Naczelny Sąd Administracyjny w pełni podziela stanowisko WSA w Krakowie dotyczące kwalifikacji spornej działki.

${ }^{35}$ Wyrok WSA w Gliwicach z 30 VII 2014 r., sygn. II SA/Gl 335/14, LEX nr 1519827. 
WSA w Warszawie z 21 listopada 2012 r. W wyroku tym zapadły rozstrzygnięcia na gruncie sporu o zwrot płatności z tytułu wspierania działalności rolniczej na obszarach o niekorzystnych warunkach gospodarowania. Sąd podkreślił, że

zgodnie z utrwalonym orzecznictwem, dane z ewidencji gruntów i budynków, o których mowa w art. 21 Ustawy z dnia 17 maja 1989 r. - Prawo geodezyjne i kartograficzne mogą stanowić dokument wyjściowy dla ustalenia danego stanu faktycznego, ale wyłącznie w wypadku, gdy są zgodne ze stanem faktycznym ${ }^{36}$.

Biorąc pod uwagę całokształt argumentacji powoływanej w powyższych orzeczeniach, uprawniony wydaje się wniosek, że pomimo wyraźnie dwutorowego orzecznictwa sądowoadministracyjnego przeważający i znajdujący lepsze oparcie w materiale normatywnym jest jednak pogląd, iż organy administracyjne przy ustalaniu leśnego charakteru danego gruntu nie są związane danymi zawartymi w ewidencji gruntów i budynków. Należy jednak zaznaczyć, że inaczej sytuacja wygląda na gruncie postępowań dotyczących kwestii podatkowych.

\subsection{Znaczenie wpisu w ewidencji w postępowaniach podatkowych}

Podkreślić należy, że powyżej przedstawione rozważania dotyczące znaczenia wpisu w ewidencji gruntów i budynków dla klasyfikacji danego gruntu jako lasu aktualne są jedynie na gruncie spraw wynikłych na podstawie przepisów ustaw o charakterze innym niż podatkowe, takich jak np. Ustawa z dnia 28 września 1991 r. o lasach ${ }^{37}$, Ustawa z dnia 16 kwietnia 2004 r. o ochronie przyrody ${ }^{38}$, czy też Ustawa z dnia 3 lutego 1995 r. o ochronie gruntów rolnych i leśnych ${ }^{39}$.

Rozważania te nie mają natomiast zastosowania do spraw związanych $z$ ustaleniem zakresu gruntów objętych podatkiem leśnym. Wskazać należy bowiem, że w tych sprawach zastosowanie znajduje przepis art. 1 ust. 2 Ustawy z dnia 30 października 2002 r. o podatku leśnym ${ }^{40}$, który expressis verbis stanowi, iż lasem $\mathrm{w}$ rozumieniu ustawy są grunty leśne sklasyfikowane w ewidencji gruntów i budynków jako lasy.

\footnotetext{
${ }^{36}$ Wyrok WSA w Warszawie z 21 XI 2012 r., sygn. V SA/Wa 1855/12, LEX nr 1338655.

${ }^{37}$ Tekst jedn. Dz.U. 2017, poz. 788.

${ }^{38}$ Tekst jedn. Dz.U. 2016, poz. 2134 ze zm.

${ }^{39}$ Tekst jedn. Dz.U. 2015, poz. 909 ze zm.

${ }^{40}$ Tekst jedn. Dz.U. 2016, poz. 374 ze zm.
} 
W sprawach dotyczących podatku leśnego decydujące znaczenie dla klasyfikacji danego gruntu jako lasu ma zatem każdorazowo wpis do ewidencji gruntów i budynków. Także przepis art. 1a ust. 3 pkt 2 Ustawy z dnia 12 stycznia 1991 r. o podatkach i opłatach lokalnych ${ }^{41}$ wprost stanowi, że na gruncie tej ustawy przez lasy rozumie się tereny sklasyfikowane $w$ ten sposób w ewidencji gruntów i budynków. Oznacza to, iż w sprawach podatkowych w zakresie klasyfikacji danego gruntu organy związane są treścią wpisu w ewidencji gruntów i budynków. Stanowisko takie jest jednolicie przyjmowane w orzecznictwie. Jako przykład można podać tutaj chociażby wyrok NSA z 2 sierpnia 2016 r., w którym wyraźnie stwierdzono, iż

art. 1 ust. 2 ustawy z dnia 30 października 2002 r. o podatku leśnym [...] stanowi, że lasem $\mathrm{w}$ rozumieniu tej ustawy są grunty leśne sklasyfikowane w ewidencji gruntów i budynków jako lasy. Natomiast [...] art. 1a ust. 3 ustawy z dnia 12 stycznia $1991 \mathrm{r}$. o podatkach i opłatach lokalnych również wprost odwołuje się do ewidencji gruntów i budynków jako podstawy wymiaru podatków. W orzecznictwie zauważa się, że tym samym również na gruncie ustaw podatkowych ewidencja ta zyskała walor normatywny dla wyznaczania zakresu opodatkowania ${ }^{42}$.

Co jednak istotne, nawet przed wejściem w życie powołanych powyżej przepisów ustawy o podatku leśnym oraz ustawy o podatkach i opłatach lokalnych sądy administracyjne jednolicie wskazywały na wiążący charakter danych zawartych w ewidencji gruntów i budynków, w sprawach o charakterze podatkowym powołując się na szeroko omawiany w poprzednich punktach art. 22 ust. 1 Ustawy z dnia 17 maja 1989 r. Prawo geodezyjne i kartograficzne.

Podstawą linii orzeczniczej wyrażającej powyższy pogląd była uchwała NSA z 18 listopada 2013 r., w której sąd stwierdził m.in., że

co do zasady o sposobie kwalifikacji gruntu (budynku), dla celów podatkowych w podatku od nieruchomości, nie tyle decyduje sposób rzeczywistego wykorzystania nieruchomości, ile jej funkcje wskazane w ewidencji gruntów i budynków ${ }^{43}$.

${ }^{41}$ Tekst jedn. Dz.U. 2016, poz. 716 ze zm.

${ }^{42}$ Wyrok NSA z 2 VIII 2016 r., sygn. II FSK 2056/14, LEX nr 2101503. Tożsame poglądy NSA wyraził także np. w: wyroku z 13 I 2015 r., sygn. II FSK 3108/12, LEX nr 1580045; wyroku z 22 XI 2016 r., sygn. II FSK 1657/16, LEX nr 2190416, czy też wyroku z 2 VIII 2016 r., sygn. II FSK 2057/14, LEX nr 2101504.

${ }^{43}$ Uchwała NSA z 18 XI 2013 r., sygn. II FPS 2/13, LEX nr 1388356. Tożsamy pogląd wyraził NSA także m.in. w wyroku z 13 I 2010 r., sygn. II FSK 1243/08, LEX nr 558871. 
W kontekście klasyfikowania na gruncie podatkowym danego gruntu jako lasu przed wejściem powołanych wyżej przepisów warto natomiast wskazać trzy wyroki NSA wydane 21 grudnia 2012 r., w których sąd wskazał, iż

co prawda dopiero od 1 stycznia $2007 \mathrm{r}$. dodano do art. 1a ustawy o podatkach i opłatach lokalnych jej ust. 3 stanowiący w pkt 2, że przez użyte w ustawie określenie lasy rozumie się grunty sklasyfikowane w ten sposób w ewidencji gruntów i budynków. Jednakże już co do stanu prawnego sprzed wejścia w życie tego przepisu w judykaturze wyrażany był konsekwentnie pogląd, że od reguły potwierdzonej treścią art. 21 ust. 1 prawo geodezyjne i kartograficzne nie zostały przewidziane żadne wyjątki, a organy ustalające wysokość zobowiązań podatkowych nie są uprawnione do przyjęcia innej podstawy wymiaru podatku niż dane wskazane $\mathrm{w}$ ewidencji gruntów. [...] Tym samym należy podzielić poglądy prezentowane $\mathrm{w}$ judykaturze, że o tym, czy dany grunt jest lasem $w$ rozumieniu art. 3 pkt 1 ustawy z dnia 28 września 1991 r. o lasach, decyduje co do zasady, w pierwszej kolejności zapis w ewidencji gruntów. Tego dowodu nie mogą samodzielnie kwestionować organy podatkowe, poprzez klasyfikowanie danego gruntu jako lasu wyłącznie w oparciu o definicję ustawową zawartą $\mathrm{w}$ ustawie o lasach i z pominięciem zapisu w ewidencji ${ }^{44}$.

W kontekście powołanych wyżej wyroków i aktualnej treści przepisów zarówno Ustawy z dnia 30 października 2002 r. o podatku leśnym, jak i Ustawy z dnia 12 stycznia 1991 r. o podatkach i opłatach lokalnych należy zatem z całą pewnością stwierdzić, że na gruncie tych ustaw decydujący dla klasyfikacji danego gruntu jako lasu jest wpis w ewidencji gruntów i budynków, który nie może być w toku postępowań kwestionowany przez organy podatkowe.

Podsumowując rozważania odnoszące się do znaczenia danych zawartych w ewidencji gruntów i budynków dla zakwalifikowania danego gruntu jako lasu, należy stwierdzić, że kwestia związania organów administracji publicznej wpisem w ewidencji gruntów i budynków nie jest jednoznacznie rozstrzygnięta w orzecznictwie. Powszechnie przyjmuje się jedynie, że wpis do ewidencji jest decydujący w sprawach dotyczących kwestii podatkowych. W sporach wynikłych na gruncie ustaw o charakterze innym niż podatkowe orzecznictwo w zakresie tej

${ }^{44}$ Wyrok NSA z 21 XII 2012 r., sygn. II FSK 984/11, LEX nr 1364168; wyrok NSA z 21 XII 2012 r., sygn. II FSK 985/11, LEX nr 1364169; wyrok NSA z 21 XII 2012 r., sygn. II FSK 986/11, LEX nr 1415193. Analogiczny pogląd na gruncie stanu prawnego sprzed wejścia w życie Ustawy z dnia 30 października 2002 r. o podatku leśnym wyraził NSA także w wyroku z 29 VI 2006 r., sygn. II FSK 842/05, LEX nr 242985. 
problematyki jest natomiast dwutorowe. Przeważający wydaje się jednak pogląd o niezwiązaniu organów administracji wpisem do ewidencji i o konieczności dokonywania każdorazowej oceny stanu faktycznego występującego $\mathrm{w}$ danej sprawie. W ocenie autorów pogląd ten zasługuje na aprobatę, zważyć należy bowiem, że wpisy w ewidencji gruntów i budynków często są nieaktualne i opieranie rozstrzygnięć jedynie na nich, bez badania stanu faktycznego, może prowadzić do wydawania orzeczeń, które ciężko będzie zaakceptować, np. do uznania za las gruntu, który od kilkunastu lat pozbawiony jest drzew i wykorzystywany na cele zupełnie niezwiązane z gospodarką leśną.

Dodatkowo wskazać należy także, że brak jest w przepisach prawa jednoznacznej podstawy, przesądzającej o tym, że organy, ustalając leśny charakter danego terenu w sprawach innych niż podatkowe, związane są treścią wpisu w ewidencji gruntów i budynków. Ewentualną podstawę takiego twierdzenia mógłby stanowić jedynie przepis art. 21 ust. 1 Ustawy z dnia 17 maja 1989 r. Prawo geodezyjne i kartograficzne, przy czy należy zauważyć, że nie przesądza on w sposób jednoznaczny o związaniu organów danymi zawartymi w ewidencji, lecz stanowi tylko, że mają one być podstawą działań organów administracji w określonych kategoriach spraw. Dlatego też wydaje się, że bardziej zasadne jest przyjęcie, iż przepis ten ustanawia wyłącznie domniemanie zgodności danych zawartych w ewidencji ze stanem faktycznym, które może jednak zostać obalone.

\section{Podsumowanie}

Reasumując całość poczynionych rozważań dotyczących definicji lasu znajdującej się w art. 3 Ustawy z dnia 28 września 1991 r. o lasach, stwierdzić należy, że wykładnia tego pojęcia nastręcza wielu problemów spowodowanych w dużej mierze niejednoznaczną redakcją treści przepisu. Ponadto podejmowanie rozstrzygnięć o zakwalifikowaniu danego gruntu jako lasu w konkretnych sprawach komplikuje brak przepisów, które jednoznacznie przesądzają o znaczeniu wpisu do ewidencji gruntów i budynków w postępowaniach innych niż podatkowe.

Prowadzi to do funkcjonowania wielu wzajemnie wykluczających się poglądów zarówno w praktyce działania organów administracji publicznej, jak i w orzecznictwie sądowoadministracyjnym. Niewątpliwie, negatywnie przekłada się to na poczucie pewności prawa obywateli. 
Należy zatem jednoznacznie postulować de lege ferenda doprecyzowanie przepisu art. 3 u.l., tak aby jego redakcja nie nastręczała wątpliwości interpretacyjnych. W ocenie autorów w pracach legislacyjnych podążać należy za kierunkiem wyznaczonym przez Sąd Najwyższy w obszernie cytowanym wyroku z dnia 28 stycznia 2009 r., sygn. IV CSK 353/08, i wyraźnie wskazać w treści ustawy, że lasem jest każdy grunt o zwartej powierzchni co najmniej 0,10 ha pokryty roślinnością leśna, a nadto także grunt przejściowo pozbawiony roślinności leśnej, jeżeli spełnia któreś z trzech kryteriów funkcjonalnych. Pozwoli to bowiem uniknąć sytuacji, gdy za las w znaczeniu prawnym nie będzie mógł zostać uznany grunt mający w sposób oczywisty taki charakter w sensie biologicznym, np. rozległy grunt pokryty roślinnością leśna, niespełniający jednak żadnej przesłanki funkcjonalnej.

Zmieniona treść przepisu art. 3 u.l. mogłaby brzmieć następująco:

Lasem w rozumieniu ustawy jest grunt:

1) o zwartej powierzchni co najmniej 0,10 ha pokryty roślinnością leśną (uprawami leśnymi) - drzewami i krzewami oraz runem leśnym;

1a) o zwartej powierzchni co najmniej 0,10 ha przejściowo pozbawiony roślinności, o której mowa w pkt 1 :

a) przeznaczony do produkcji leśnej lub

b) stanowiący rezerwat przyrody lub wchodzący w skład parku narodowego albo

c) wpisany do rejestru zabytków;

2) związany z gospodarką leśna, zajęty pod wykorzystywane dla potrzeb gospodarki leśnej: budynki i budowle, urządzenia melioracji wodnych, linie podziału przestrzennego lasu, drogi leśne, tereny pod liniami energetycznymi, szkółki leśne, miejsca składowania drewna, a także wykorzystywany na parkingi leśne i urządzenia turystyczne.

Wydaje się natomiast, że trudno byłoby za pomocą metod legislacyjnych jednoznacznie rozwikłać wątpliwości dotyczące znaczenia wpisu danego gruntu do ewidencji gruntów i budynków w postępowaniach innych niż podatkowe. Zdaniem autorów ocena charakteru danego gruntu powinna być oparta na każdorazowej analizie stanu faktycznego oraz prawnego przez organ wydający decyzję w konkretnej sprawie. Organ powinien zatem posiłkować się zarówno danymi zawartymi w ewidencji gruntów i budynków, jak i dokonanymi przez siebie ustaleniami faktycznymi, dokonując kompleksowej oceny cech danego gruntu. Ciężko bowiem wyobrazić sobie wprowadzenie przepisów, które wprost wskazywałyby, że organy administracyjne w określonych kategoriach 
spraw (innych niż podatkowe) nie są związane sklasyfikowaniem danego gruntu w ewidencji. W tym zakresie pozostaje zatem zdanie się na orzecznictwo sądowoadministracyjne, w którym, jak zostało wskazane w treści artykułu, przeważający wydaje się właśnie pogląd o braku związania organów administracji danymi zawartymi w ewidencji gruntów i budynków przy wydawaniu rozstrzygnięć dotyczących klasyfikacji danego gruntu jako lasu na gruncie spraw innych niż podatkowe.

\section{ISSUES RELATED TO THE DEFINITION OF A FOREST UNDER THE POLISH LEGAL SYSTEM}

\section{S u m m a ry}

The article touches upon the controversies around the definition of a forest contained in the provision of Article 3 of the Act of 28 September 1991 on forests, present in the doctrine as well as in judicial decisions in administrative law. The interpretation of the above provision is analysed and the views presented in the doctrine and the judicial rulings, which sometimes include contradicting arguments, are examined.

In the first part of the article individual elements of the definition of a forest have been identified and the difficulties with their interpretation that have led to the emergence of a vast number of judicial decisions and rulings delivered by administrative courts as well as the Supreme Court have been presented. The second part contains deliberations on the importance of the data included in the land and buildings register and their potential use for the classification of land as a forest on the grounds of concrete administrative proceedings, including these on tax matters. In this context the normative value of the provisions of the Act of 17 May 1989: Geodetic and Cartographic Law and individual tax laws making these data binding and applicable has been examined as well. Also this latter issue generates frequently diverging opinions expressed by administrative courts. The last part of the paper contains de lege lata and de lege ferenda postulates intended to reconcile the presented controversies connected with the classification of individual land as forest. The authors hope that implementation of these postulates will contribute to the unification of the judiciary opinions regarding the concept of a forest and consequently will help to eliminate the existing doubts.

Keywords: forests - Act on forests - forest land - register of buildings and land classification of land 